\title{
Evaluation of Some Allergic Mediators in Elderly Individuals
}

\author{
M. M. Bahgat and M. I. Michael \\ Biological Applications Dept, Nuclear Research Centre (NRC), \\ Enshas, Egypt.
}

\begin{abstract}
GING is a physiological process characterized by decreasing adaptation of the individual and accentuation of certain mechanisms e.g. arteriosclerotic plaque formation, oxidative stress and autoimmune diseases. Therefore, the present study was planned to evaluate immunosenescence on some allergic mediators in healthy individuals.

Twenty-four male volunteers arranged into three groups according to their age were participated in this study. After their permission, personal and family history, full clinical examination and several laboratory confirmatory tests were determined to assure their healthy condition. Forty-eight $\mathrm{h}$ later another blood specimen was withdrawn where, complete blood picture, total immunoglobulin E (IgE), interleukin-4 (IL4), interleukin-5 (IL5) and $\gamma$-interferon $(\gamma$-INF) were estimated.

Regarding the allergic mediators estimated in the present study, the third geriatric group had relative eosinophilia, positive correlation between IgE and $\gamma$-INF and high significant decrease in $\operatorname{IgE}$ and IL5. These results led to the conclusion that the immunosenescence in this group of individuals did not lead to any allergic related conditions and the impairment of functions associated with aged immune response most probably had no role on the prevalence of allergic disease in elderly individuals. Keywords: Allergy, blood picture, eosinophils, cytokines.
\end{abstract}

It is well known that the immune system is a defence mechanism that provides rapid, specific and very protective response against invading microorganisms (Litman et al., 2005). The immune response is a complex and regulated sequence of events involving several cell types; this immune response exerts its effects mainly through cellular and humeral immunity and the master cell in the immune system is the lymphocyte. Aging is a physiological process concerning decreasing ability of the individuals to adapt to environmental stress.

The clinical consequences include increase atherogenic factors, oxidative stress, malignancy, autoimmunity and increased susceptibility to infection (Cardona et al., 2011). 
Aging of the immune system (immunosenescence) plays a contributory role in the pathogenesis of age related diseases and disability of the physical fitness of healthy elderly individuals. This impact is probably a result of diversity in the T-cell receptor and B-cell receptor repertoire owing to the accumulation of dysfunctional cells (Cardona et al., 2011 and Pawelec, 2007).

Allergic diseases are often thought of as childhood disorders, however the prevalence of allergic diseases in the elderly is estimated around 5-10\% (Kuokkanen, 1972 and Mathur, 2010), whether this allergic condition is related to dys-regulation or impaired function in the aged immune system or it is a childhood disorder and occasionally makes its appearance in old age need further research.

Therefore, the aim of the present study is to determine the value of some allergic mediators in healthy elderly individuals and to correlate each parameter with the others in an attempt to throw a light on the aetiology of geriatric allergy.

\section{Subjects and Methods}

Twenty-four males, 30-65 years, were participated in the present study. They were arranged equally into three groups according to their age; the first group (I) of 30-44, the second group (II) includes persons aged from 45-59 while the last group (III) comprised the volunteers from 60-65 years old. Prior to full clinical examination experienced by a physician, a personal and family history such as; age, residence, job description, smoking habits, medical treatment, type of diet, past and family history of cardiovascular diseases, allergic diseases were analyzed for each volunteer. Clinical examination included beside pulse rate, blood pressure, heart, chest and abdomen examination and any allergic manifestations in the skin, nose or lungs.

Two blood specimens were withdrawn from each volunteer. The first specimen after $8 \mathrm{~h}$ of fasting to determine erythrocyte sedimentation rate (ESR), fasting blood sugar (FBS), blood urea nitrogen (BUN), creatinine (creat), albumin (album), alanine transaminase (ALT) and triiodothyronine hormone (T3). The ESR was analyzed according to Dacie and Lewis (1995) while FBS, BUN, creat, album and ALT were evaluated calorimetrically using commercial kits (Bio-Merieux France). T3 was estimated using Multichannel Gamma Counter

Egypt. J. Rad. Sci. Applic., Vol. 27, No. 1-2 (2014) 
with RIA kits from IZOTOP (Institute of Isotopes Ltd., Budapest). The diabetic individuals as well as persons taking past or present corticosteroid therapy were excluded then the remaining volunteers were classified into three groups.

Second specimen was taken $48 \mathrm{~h}$ later. This specimen was introduced into two tubes: a heparinized one for examining complete blood picture using Micro 60 (ABX gp) for complete blood count and the other tube without anticoagulant where serum was collected for estimating IgE using BioCheck, Inc., CA, USA kit, IL4, using Ray Biotech, Inc. Narcross GA 30092 kit, IL5 and $\gamma$-IF using Boster biological technology LTD., CA, USA kit in serum using the enzymelinked immunosorbent assay (ELISA) technique with Stat Fax Reader.

Anova (one-way classification F-test), Duncan's multiple range tests and Pearson`s correlation test were used for the statistical analysis of data $(\mathrm{n}=8)$ according to Lind and Masson (1996).

\section{Results}

Table 1. summarized the results of the chosen confirmatory tests in the three tested groups. These tests included ESR, FBS, and kidney function tests: blood BUN and creat, liver function tests: ALT and album and the metabolic hormone T3. In the three groups, all these parameters are within the reference range except for ESR in the third group where the mean showed a higher value.

TABLE 1. Confirmatory laboratory parameters estimated in the three groups of individuals.

\begin{tabular}{|c|c|c|c|c|c|c|c|c|c|}
\hline \multirow[t]{2}{*}{ Parameters } & \multicolumn{3}{|c|}{ X \pm S.E. } & \multicolumn{3}{|c|}{$\begin{array}{c}\text { Upper } \\
\text { estimated value }\end{array}$} & \multicolumn{3}{|c|}{$\begin{array}{c}\text { Lower estimated } \\
\text { value }\end{array}$} \\
\hline & $\mathbf{I}$ & II & III & I & II & III & $\mathbf{I}$ & II & III \\
\hline $\operatorname{ESR}\left(1^{\mathrm{st}} \mathrm{h}\right)$ & $8.0 \pm 0.7$ & $9.3 \pm 0.9$ & $17.0 \pm 1.9$ & 9 & 10 & 19 & 6 & 6 & 15 \\
\hline $\begin{array}{c}\text { FBS } \\
\mathrm{mg} / \mathrm{dl}\end{array}$ & $87.0 \pm 1.2$ & $99.0 \pm 2.0$ & $92.0 \pm 1.9$ & 91 & 110 & 115 & 79 & 82 & 88 \\
\hline $\begin{array}{l}\text { BUN } \\
\mathrm{mg} / \mathrm{dl}\end{array}$ & $17.0 \pm 1.2$ & $18.1 \pm 1.0$ & $19.1 \pm 0.9$ & 18.5 & 20.1 & 22 & 12.1 & 14.0 & 15.2 \\
\hline $\begin{array}{l}\text { Creat } \\
\mathrm{mg} / \mathrm{dl}\end{array}$ & $0.7 \pm 0.02$ & $0.8 \pm 0.03$ & $1.0 \pm 0.05$ & 0.9 & 0.99 & 1.2 & 0.5 & 0.5 & 0.7 \\
\hline $\begin{array}{l}\text { ALT } \\
\text { IU/L }\end{array}$ & $7.0 \pm 1.1$ & $6.0 \pm 1.0$ & $7.0 \pm 1.3$ & 8.9 & 9 & 11 & 6 & 6 & 5.9 \\
\hline $\begin{array}{l}\text { Album } \\
\mathrm{g} / \mathrm{dl}\end{array}$ & $4.0 \pm 0.12$ & $4.2 \pm 0.23$ & $3.9 \pm 0.35$ & 4.9 & 4.5 & 4.9 & 3.8 & 3.7 & 3.1 \\
\hline $\begin{array}{c}\text { T3 } \\
\text { ng/dl }\end{array}$ & $90.3 \pm 3.9$ & $77.8 \pm 4.1$ & $\begin{array}{c}102.1 \pm \\
6.3\end{array}$ & 99 & 89 & 112 & 70 & 68 & 81 \\
\hline
\end{tabular}

Values with different superscript in the same row differ significantly $(p<0.05), *(p<0.01)$.

Egypt. J. Rad. Sci. Applic., Vol. 27, No. 1-2 (2014) 
Table 2. illustrated the data of the blood picture, total IgE, IL4, IL5 and $\gamma$ INF in the three tested groups. The haemoglobin concentration $(\mathrm{Hb})$, staff neutrophils and total $\mathrm{IgE}$ showed significant changes between the three groups; group I showed the highest level in $\mathrm{Hb}$ followed by group II $(p<0.01)$ then group III $(p<0.01)$. To the contrary, the highest value for staff neutrophils and total IgE was observed in group II followed by group III for staff $(p<0.01)$ and group I for $\operatorname{IgE}(p<0.01)$. The red blood cells (RBCs) in group I showed high significant increase $(p<0.01)$ compared to the other two groups while platelets experienced high significant $(p<0.01)$ decrease in the third group compared to the first two groups. The total leucocytes count (TLC) and segmented neutrophils in the second group demonstrated significant increase compared to each of group I and II with no significant changes between these two later groups. The lymphocytes, monocytes and eosinophils followed the same statistical trend; the three types of TLC showed significant decrease in the first group compared to the other two groups; at the mean time no significant change was detected between group II and group III in these three parameters. Among the three cytokines examined in this study, only IL5 showed significant changes, where group III experienced high significant decrease $(p<0.01)$ compared to the first two groups.

TABLE 2. The statistical data of blood picture, total IgE, IL4, IL5 and $\gamma$-INF in the three tested groups of individuals.

\begin{tabular}{|c|c|c|c|}
\hline Parameters & Group I & Group II & Group III \\
\hline Hb $(\mathrm{g} / \mathrm{dl})$ & $14.08 \pm 0.17^{\mathrm{a}}$ & $13.00 \pm 0.17^{\mathrm{b}^{*}}$ & $10.56 \pm 0.160^{\mathrm{c}^{*}}$ \\
\hline RBCs $\left(\times 10^{6}\right)$ & $4.36 \pm 0.08^{\mathrm{a}}$ & $3.94 \pm 0.08^{b^{*}}$ & $3.24 \pm 0.140^{\mathrm{b}^{*}}$ \\
\hline Platelets $\left(\mathrm{x} 10^{3}\right)$ & $211.00 \pm 3.37^{\mathrm{a}}$ & $213.00 \pm 6.90^{\mathrm{a}}$ & $161.00 \pm 4.240^{\mathrm{b}^{*}}$ \\
\hline TLC $\left(x 10^{3}\right)$ & $6028.00 \pm 150.56^{b^{*}}$ & $7571.00 \pm 230.60^{\mathrm{a}}$ & $6557.00 \pm 198.5^{b^{*}}$ \\
\hline Staff & $57.00 \pm 1.86^{\mathrm{c}^{*}}$ & $84.00 \pm 5.67^{\mathrm{a}}$ & $66.00 \pm 1.990^{\mathrm{b}^{*}}$ \\
\hline Segmented & $4228.00 \pm 59.89^{\mathrm{b}^{*}}$ & $5361.00 \pm 229.90^{\mathrm{a}}$ & $4444.00 \pm 169.6^{b^{*}}$ \\
\hline Lymphocytes & $1611.00 \pm 74.87^{b}$ & $2020.00 \pm 56.10^{\mathrm{a}^{*}}$ & $1921.00 \pm 74.820^{\mathrm{a}}$ \\
\hline Monocytes & $125.00 \pm 5.90^{\mathrm{b}}$ & $155.00 \pm 10.39^{\mathrm{a}}$ & $163.00 \pm 11.110^{\mathrm{a}}$ \\
\hline Eosinophils & $55.00 \pm 2.24^{\mathrm{b}}$ & $67.00 \pm 3.28^{\mathrm{a}}$ & $72.00 \pm 3.380^{\mathrm{a}}$ \\
\hline IgE (IU/ ml) & $400.00 \pm 25.71^{\mathrm{b}^{*}}$ & $570.00 \pm 22.85^{\mathrm{a}}$ & $200.00 \pm 15.630^{\mathrm{c}^{*}}$ \\
\hline IL4 (pg/ ml) & $0.29 \pm 0.02^{\mathrm{a}}$ & $0.27 \pm 0.04^{\mathrm{a}}$ & $0.28 \pm 0.040^{\mathrm{a}}$ \\
\hline IL5 (pg/ ml) & $25.83 \pm 3.42^{\mathrm{a}}$ & $24.67 \pm 6.02^{\mathrm{a}}$ & $12.00 \pm 0.970^{\mathrm{b} *}$ \\
\hline $\boldsymbol{\gamma}$-INF (pg/ ml) & $9.17 \pm 1.56^{\mathrm{a}}$ & $9.67 \pm 2.24^{\mathrm{a}}$ & $6.30 \pm 1.300^{\mathrm{a}}$ \\
\hline
\end{tabular}

Values with different superscript in the same row differ significantly $(p<0.05), *(p<0.01)$.

Table 3. visualized the correlation between eosinophils and IgE in addition to the three cytokines in the three groups. There is no significant correlation in group I while eosinophils showed a significant negative correlation $(p<0.05)$ with

Egypt. J. Rad. Sci. Applic., Vol. 27, No. 1-2 (2014) 
IgE and positive correlation ( $p<0.05)$ with IL5 in group II and high positive correlation ( $p<0.01$ ) with IL4 in group III. and $\gamma$-INF in the third group.

TABLE 3. Correlation coefficient (r) between eosinophiles and each of IgE, IL4, IL5 and $\gamma$-INF in the three tested groups.

\begin{tabular}{|c|c|c|c|c|c|c|c|c|c|c|c|}
\hline \multicolumn{4}{|c|}{ Group I } & \multicolumn{4}{c|}{ Group II } & \multicolumn{4}{c|}{ Group III } \\
\hline IgE & IL4 & IL5 & INF & IgE & IL4 & IL5 & $\boldsymbol{\gamma}$-INF & IgE & IL4 & IL5 & $\boldsymbol{\gamma}$-INF \\
\hline \multirow{2}{*}{0.49} & -ve & & & $*$-ve & & $*$ & $-v e$ & $-v e$ & $* *$ & $-v e$ & \\
& 0.27 & 0.17 & 0.12 & 0.58 & 0.05 & 0.56 & 0.26 & 0.12 & 0.72 & 0.23 & 0.17 \\
\hline
\end{tabular}

Values of Correlation Coefficient are significant at the levels of $0.05 \% *$ and $0.01 \% * *$

Table 4. illustrated the correlation between $\operatorname{IgE}$ and the three tested cytokines. The only high significant positive correlation $(p<0.01)$ was observed between IgE.

TABLE 4. Correlation coefficient (r) between IgE and the three tested cytokines in the three groups.

\begin{tabular}{|c|c|c|c|c|c|c|c|c|}
\hline \multicolumn{3}{|c|}{ Group I } & \multicolumn{3}{c|}{ Group II } & \multicolumn{3}{c|}{ Group III } \\
\hline IL4 & IL5 & $\boldsymbol{\gamma}$-INF & IL4 & IL5 & $\boldsymbol{\gamma}$-INF & IL4 & IL5 & $\boldsymbol{\gamma}$-INF \\
\hline & $-\mathrm{ve}$ & $-\mathrm{ve}$ & $-\mathrm{ve}$ & & & $-\mathrm{v}$ & & $* *$ \\
0.13 & 0.14 & 0.36 & 0.28 & 0.08 & 0.22 & 0.36 & 0.42 & 0.76 \\
\hline
\end{tabular}

Values of Correlation Coefficient are significant at the level $0.01 \% * *$.

\section{Discussion}

Demographic distribution of the population is progressively changing; people over 60 years old are one of the growing segment in developed and developing countries as well. The aging of the immune system termed as immunosenescence is a complex process affecting both the innate and the adaptive immune system. The alteration in aged immune response may be related to dys-regulation, impaired function and/or decreased number of immune cells. Pawelec (2007) noticed increased susceptibility of the elderly to infectious diseases and referred this enhancement to loss of the declining stemcell function and the resultant decline of the follicular B-cell compartment.

Atopy or allergy can be defined as a condition with certain specific immunologic and clinical features. Immunological atopy responds by continual production of IgE antibodies; eosinophils have receptors for IgE and IL5 (Abdelilah et al., 1998 and Egan et al., 1996) while certain cytokines have a critical role in the ability of T-lymphocytes to induce $\operatorname{IgE}$ antibody production by B-cells; IL4 enhances and $\gamma$-INF suppresses IgE responses (Oppenheim and 
Ruscetti, 1997). Therefore, in the present study we evaluate in particular these 4 parameters in order to understand the mechanism of atopy in geriatric individuals whether it is a primary one related to aged immune response or it persists earlier and can only occasionally make its initial appearance in the elderly.

The definition of older persons needs to be clarified, Cardona et al. (2011) applied the term older adults to persons 65 years or older. It is worth to mention that surrounding factors and environment differ from developed and developing countries, therefore in the present study we consider older individuals the persons having 60-65 years old. Similarly, the healthy state of the volunteers was confirmed by the clinical examinations and several laboratory tests since any underlying pathological conditions may conflict the age related declines in immune functions.

These laboratory confirmatory tests included T3, BUN, creat, ALT and album to evaluate metabolic and hormonal state, kidney and liver function respectively, in addition to fasting blood sugar, and ESR. Apart from ESR, where the mean value of the older age group was higher than the reference range, all other tested parameters were within normal values. No discussion for these values was performed since the main issue of carrying out ESR was only to assure the healthy condition of the individuals not to discuss the results. ESR is completely a nonspecific phenomenon but it is useful as a screening test in the routine medical examinations. The ESR depends on the rate of fall of the RBCs, which in turn depends upon the differences in specific gravity between red cells and the plasma, the extent by which the red cells form rouleaux, ratio of red cells to plasma, plasma viscosity and several other factors concerning the sedimentation tube (Dacie and Lewis, 1995).

In the present study, the increase in ESR values may be due to age effect and/or there is other conditions e.g. mild arthritis or any other minor inflammation that cannot be detected clinically. These results agreed with the work of Ailland et al. (1986). The former showed that elderly individuals had higher ESR compared to younger one. On the other hand, this work disagreed with that of Gudmundsson and Bjelle (1993) as he showed no significant change in ESR with age.

The reduction in the $\mathrm{Hb}$ content, $\mathrm{RBCs}$ and platelet count observed in the third group either significant or insignificant may point to bone marrow hypoplasia or decrease in some essential elements entering in the formation of

Egypt. J. Rad. Sci. Applic., Vol. 27, No. 1-2 (2014) 
these components. It seems that reduction in bone marrow matrix is not the cause in this study otherwise leucopoenia, neutropenia or both must have been clearly detected. Moreover, since leucocytes had a relatively lower life span compared to that of red cells it seems reasonable that marrow hypoplasia, if present in this group of individuals, influence more this leucoid group. In aging, there is a decrease in some essential elements, Mocchegiani et al. (2010) observed alteration in zinc homeostasis leading to low intracellular zinc content. Ahluwalia et al. (2004), in their turn, found decrease in $\mathrm{Hb}$, haematocrit and RBCs in iron deficient women group when studying the relation between immune function and iron deficiency in geriatric females. The thrombocytopenia observed in the elderly group in the present study is most probably a relative one since the reference range is from 150000-400000. Therefore, the decrease detected may be due to individual variation rather than decrease formation.

Surprisingly there were no significant differences between young individuals (group I) and old ones (group III) in the total leucocytes count and its major differential cells the segmented neutrophils; both showed significant decrease compared to middle-aged group (Table 2). This finding leads to the suggestion that aging, at least in this group of healthy individuals, had no role on the number of bone marrow white cells and confirm the findings of many authors that immunosensecence reflects impaired functions of immune cells not their numbers. These impaired functions include reduced phagocytosis, reduced reactive oxygen species production, defect in apoptotic cell death, dysregulation in function and reduced degranulation (Busse and Mathur, 2010, Dunn-Walters and Ademokun, 2010, Gomez et al., 2008 and Pawelec, 2007). The other leucocytes originating from lymphoid organs (lymphocytes) and the blood macrophages (monocytes) pointed also to the negligible role of age on their number despite its definite effect on their function.

Aging reduced response, proliferation and signal transduction of T-cell lymphocytes; as regards B-cells, it causes production of low affinity antibodies and dys-regulation in function. As for monocytes or blood macrophages age reduced phagocytosis, cytokines secretion and reduced generation of nitric oxide and superoxide (Cardona et al., 2011).

Eosinophils are bone marrow derived granulocytes that have less phagocytic and bactericidal activity than neutrophils but they are more immunogenic and they are highly degranulated in response to antigenic 
stimulation (Roberts et al., 1999). It is well known that cellular and humoral immunities are regulated by two distinct helper T-cell subsets: TH1 and TH2 for cellular and humoral immunity respectively; among the cytokines produced by TH 1 cells $\gamma$-INF and those by TH 2 are IL 4 and IL5. The imbalance between TH1 and TH2 cells towards TH2 associated with and increased risk of allergic disorders (Iwakabe et al. 1998). Therefore, can we state that the eosinophilia observed in the present study may be related to allergic conditions especially there is positive correlation between them and IL4 (Table 3).

There is several findings which contradict this view; firstly, the immunoglobulin IgE mediated diseases showed high significant decrease in the third group; secondly the high significant decrease of IL5 and insignificant change of IL4 and thirdly the positive correlation between IgE and $\gamma$-INF in the elderly group. Scichilone et al. (2011) demonstrated that serum total $\operatorname{IgE}$ comparisons between younger and older subjects without any allergic diseases showed significant lower levels in the older persons. Similarly, Kramer et al. (2000), Powe et al. (2010) and Rapp et al. (2000) experienced high increase of IgE, IL4 and IL5 in allergic individuals. Moreover, in a study performed in our lab, IL4 evaluated in allergic individuals in both sex was higher more than 7 folds that estimated in this work (unpublished data).

TH2 lymphocyte proliferation in persons with allergies induce release of their characteristic combination of cytokines including IL4 and IL5 which promote IgE production; the eosinophilia encountered in allergic diseases is thought to be mediated by IL5 (Roberts et al., 1999). A condition, if present, leads to positive correlation between eosinophils and IL5 beside the increase in this cytokine, both findings are absent in the present study where no increase in IL5 and no correlation was observed. In addition, the three groups were within the reference range of absolute number of eosinophils (40-550) and the eosinophilia noticed in the third group compared to the first group is not a true one as it reaches $1 \%$ of the total leucocytes count in the third group.

Interferon gamma is an immunoregulatory cytokine secreted by TH1 cells and tends to suppress eosinophils response (Oppenheim and Ruscetti 1997). In allergic condition, the induction of IgE was associated with suppression of TH1 cells and consequently $\gamma$-INF. In the present study the positive correlation between IgE and $\gamma$-INF abolish the allergic nature of this group.

Egypt. J. Rad. Sci. Applic., Vol. 27, No. 1-2 (2014) 
From the previous results, we may conclude that despite the relative eosinophilia and the positive correlation between the eosinophils and IL4 in the elderly group there is no tendency in this healthy group of male subjects to develop allergic related conditions as evidenced by decrease IgE, IL5 and positive correlation between IgE and $\gamma$-INF.

\section{References}

Abdelilah, S. G., Bouchaïb, L., Morita, M., Delphin, A., Marika, S., André, C. and Monique, C. (1998) Molecular characterization of the low affinity IgE receptor FceRII/CD23 expressed by human eosinophils. Int. Immunol., 10, 395.

Ahluwalia, N., Sun, J., Krause D., Mastro, A., and Handte, G. (2004) Immune function is impaired in iron-deficient, homebound, older women. Am. J. Clin. Nutr., 79, 516.

Aillaud, M. F., Pignol, M. C., Alessi, M. C., Harol, J. R., Escande, M., Mongin, M. and Juhan-Vaque, L. (1986) Increase in plasma concentration of plasminogen activator inhibitor, fibrinogen, Von wille brand factor, Factor VIII: C and in erythrocyte sedimentation rate with age. Thromb. Haemost., 55, 330.

Busse, P. J. and Mathur, S. K. (2010) Age-related changes in immune function: effect on airway inflammation. J. Allergy Clin. Immunol., 126, 690.

Cardona, V., Guilarte, M., Luengo, O., Labrador-Horrillo, M., Sala-Cunill, A. and Garriga, T. (2011) Allergic diseases in the elderly, Clin. Transl. Allergy, 1, 11.

Dacie, J. V. and Lewis, S. M. (1995) Practical Haematology. Eighth edition, Longman Group.

Dunn-Walters, D. K. and Ademokun, A. A. (2010) B-cell repertoire and aging. Curr. OpinImmunol., 22, 514.

Egan, R. W., Umland, S. P., Cuss, F. M. and Chapman, R. W. (1996) Biology of interleukin-5 and its relevance to allergic disease. Allergy, 51, 71.

Gomez, C. R., Nomellini, V., Faunce, D. E. and Kovacs, E. J. (2008) Innate immunity and aging. Exp. Gerontol., 43, 718.

Gudmundsson, M. and Bjelle, A. (1993) Plasma, serum and whole blood viscosity variations with age, sex and smoking habits. Angiology, 44, 384.

Iwakabe, K., Shimada, M., Ohta A., Yahata, T., Ohmi, Y., Habu, S. and Nishimura, T. (1998) The restraint stress drives a shift in Th1/Th2 balance toward Th2-dominant immunity in mice. Immunol. Lett., 62, 39.

Kramer, M. F., Ostertag, P., Pfrogner, E. and Rasp, G. (2000) Nasal interleukin-5, immunoglobulin E, eosinophilic cationic protein, and soluble intercellular adhesion molecule-1 in chronic sinusitis, allergic rhinitis, and nasal polyposis. Laryngoscope, 110, 1056. 
Kuokkanen, L. (1972) Drugs eruptions: a series of 464 cases in the Department of Dermatology University of Tineku, Finland during 1966-1970. Acta. Allergol., 27, 407.

Lind, D. A. and Masson, D. R. (1996) Statistical Techniques in Business and Economics (ninth Editions) Ed. By Irwin MC; Grow-Hill, USA, 433-443.

Litman, G., Cannon, J. and Dishaw, L. (2005) Reconstructing immune phylogeny: new perspectives. Nat. Rev. Immunol., 5, 866.

Mathur, S. K. (2010) Allergy and asthma in the elderly. Semin. Respir. Crit. Care Med., 31, 587.

Mocchegiani, E., Malavolta, M., Costarelli, L., Giacconi, R., Cipriano, C., Piacenza, F., Tesei, S., Basso, A., Pierpaoli, S. and Lattanzio, F. (2010) Zinc, metallothioneins and immunosenescence. Proc. Nutr. Soc., 69, 290.

Oppenheim, J. J. and Ruscetti, F. W. (1997) Cytokines. In: Medical Immunology (ninth edition) ed. By Stites, D.P.; Terr, A.I. and Parslow, T.G.; California, USA; 10,146.

Pawelec, G. (2007) Immunosenescence comes of age. Symposium on Aging Research in Immunology: The Impact of Genomics. EMBO reports, 8, 220.

Powe, D. G., Kormelink, T. G., Sisson, M., Blokhuis, B. J., Kramer, M. F., Jones, N. S. and Redegeld, F. A. (2010) Evidence for the involvement of free light chain immunoglobulins in allergic and nonallergic rhinitis. J. Allergy Clin. Immunol., 125, 139.

Rapp, J., Kosa, L., Halasz, A., Kereki, E. and Borzsonyi, L. (2000) Levels of interleukin-4, interleukin-5, tryptase and eosinophil cationic protein of nasal lavage fluid in pollen allergic rhinitis. Orv. Hetil., 141, 1919.

Roberts, P. J., Linch, D.C. and Webb, D. K. H. (1999) Phagocytosis In: Postgraduate Haematology (fourth edition) ed. By Hoffbrand, A.V.; Lewis, S.M. and Tuddenhan, E.G.D.; London, England; 12, 235.

Scichilone, N., Callari A., Augugliaro, G., Marchese, M., Togias, A. and Bellia, V. (2011) The impact of age on prevalence of positive skin prick tests and specific IgE tests. Respir. Med., 105, 651.

(Received: 15/12/2013;

accepted: 26/01/2014)

Egypt. J. Rad. Sci. Applic., Vol. 27, No. 1-2 (2014) 


\title{
تقييم بعض وسائط الحساسية فى الأفراد المتقدمين فى السن
}

ميرفت محمود بهجت ، و ميخائيل إبر اهيم ميخائيل

قسم التطبيقات البيولوجية ـ مركز البحوث النووية ــ هيئة الطاقة الذرية

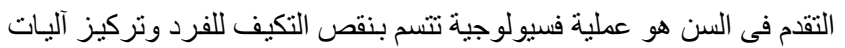

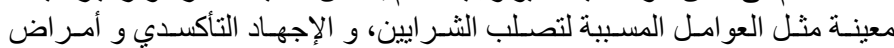

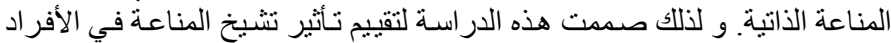
الأصحاء من خلال تقدير بعض وساعة وسائط الحساسية.

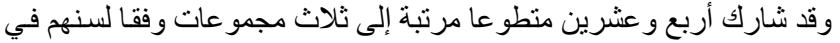

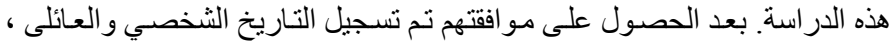

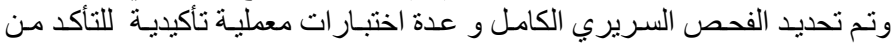

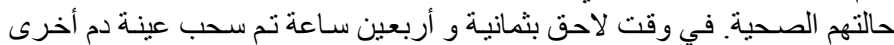

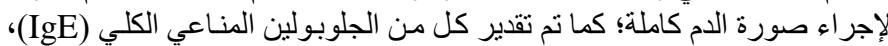

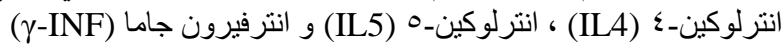

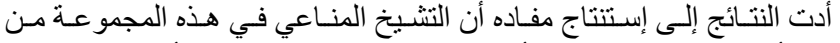

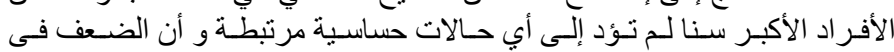

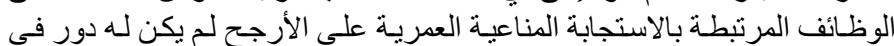
انتشار أمر اض الحساسية في الأفر اد المسنين وفقال الهذه النتائج.
\end{abstract}

